ISSN (print): 1698-6180. ISSN (online): 1886-7995

www.ucm.es/info/estratig/journal.htm

Journal of Iberian Geology 38 (1) 2012: 7-8

http://dx.doi.org/10.5209/rev_JIGE.2012.v38.n1.39202

\title{
Preface
}

\section{Active Faults in Iberia}

Detection and characterization of seismic sources are essential for obtaining realistic values of the seismic hazard in the Iberian Peninsula. The relatively low slip-rates yield high recurrence intervals of major and potentially destructive earthquakes in this area. The seismic catalog, which barely covers the last 2000 years, is therefore too short to obtain information from a complete seismic cycle. Thus, the geology and especially the paleoseismic record of active faults are indispensable tools to estimate and quantify the real seismogenic potential of Iberian active faults and the seismic hazard in the area. Active faults in Iberia have been detected and characterized. These geological data should be included in the seismic catalogs of Spain and Portugal in order to gain a better understanding of the seismic phenomena in the Peninsula.

In recent years, an increasing number of active faults have been detected and characterized in the Iberian Peninsula. This trend has been accompanied by international initiatives such as the SHARE project (www.share-eu. org/) and the Global Earthquake Model; GEM (www. globalquakemodel.org), which seek to regularize, at both European and worldwide levels, the methodologies for calculating seismic hazard on the basis of geological data from active faults. In October 2010, the IBERFAULT 2010 meeting (First Iberian Meeting on Active Faults and Paleoseismology, http://www.iberfault.org/ iberfault_2010/) was held in Siguenza (Spain), bringing together a large number of specialists. The aim of the meeting was to discuss the state of the art of the parameterization of active faults in the Iberian Peninsula and to consider the need for incorporating geological data from seismogenic faults in the seismic hazard analysis. One of the conclusions of the meeting was to give an impetus to the publication of a special issue dedicated to active faults in Iberia. Reviews of active faults or seismotectonic areas and the parameterization of individual faults were considered to be of outstanding interest. With the publication of this volume we have fulfilled our objective. This special issue is concerned with the latest research on active faults in Iberia, which is of interest to the scientific community engaged in the study of active tectonics of slow active faults, and to specialists in the implementation of geological data in seismic hazard assessment.

The volume contains research papers and a technical report. The papers are classified by seismotectonic regions and contain the results of studies undertaken on specific faults or geological units with evidence of Quaternary activity in the Iberian Peninsula. The geological parameters extracted are necessary to characterize the seismic activity of faults (maximum magnitude, slip rate, level of activity, recurrence interval, etc.). The technical report describes the new Quaternary Active Faults Database of Iberia: QAFI (García Mayordomo et al. in this volume). QAFI is a database of faults that provide evi- 
dence of activity during the Quaternary (last 2.6 million years according to the official limit set by IQS in 2009) and is housed in the Instituto Geológico y Minero de España (IGME), which is responsible for its maintenance. It is designed for researchers and technical experts despite being accessible to the general public (http://www. igme.es/infoigme/aplicaciones/qafi/About.aspx). QAFI constitutes a first step towards obtaining more realistic seismic hazard estimations by considering the geological data from active faults.

\section{Acnowledgments}

We gratefully acknowledge the Organizing Committee of the workshop IBERFAULT 2010 for bringing together the large number of researchers in the field of active faults, and for sowing the seeds that have given rise to this volume. We are also indebted to the many researchers who have contributed to this volume

Madrid, April 2012

\author{
J.J. Martínez-Díaz \\ Universidad Complutense de Madrid \\ jmdiaz@geo.ucm.es \\ E. Masana \\ Universitat de Barcelona \\ eulalia.masana@ub.edu \\ M.A. Rodríguez-Pascua \\ Instituto Geológico y Minero de España \\ ma.rodriguez@igme.es
}

